\title{
Effect of nursery habitat degradation on flatfish population: Application to Solea solea in the Eastern Channel (Western Europe)
}

\author{
S. Rochette ${ }^{a,}{ }^{*}$, E. Rivot ${ }^{a}$, J. Morin ${ }^{b}$, S. Mackinson ${ }^{c}$, P. Riou ${ }^{d}$ and O. Le Pape ${ }^{a}$
}

\begin{abstract}
a Université Européenne de Bretagne, UMR 985 Agrocampus OUEST, INRA « Ecologie et Santé des Ecosystèmes », Ecologie halieutique, Agrocampus OUEST, 65 rue de St Brieuc, CS 84215, 35042 Rennes, France

${ }^{\mathrm{b}}$ Laboratoire Ressources Halieutiques, IFREMER, Avenue du Général de Gaulle, BP 32, 14520 Port en Bessin, France

${ }^{c}$ Lowestoft Laboratory, CEFAS, Pakefield Road, Lowestoft, Suffolk NR33 OHT, United Kingdom

d Laboratoire Environnement Ressources de Normandie, IFREMER, Avenue du Général de Gaulle, BP 32,14520 Port en Bessin, France
\end{abstract}

*: Corresponding author : S. Rochette, email address : rochette@agrocampus-ouest.fr

\begin{abstract}
:
Estuaries and coastal waters are essential nursery habitats for many marine species, and especially for flatfishes. Thus, investigating how anthropogenic disturbances affect the quality of these habitats is of major importance to understand their consequences on the population renewal of marine species.

The aim of the present study was to analyse the effects of estuarine habitat degradation on the population of the common sole in the Eastern Channel, a key species in the fish community and fisheries in this area. We especially focused on the drastic drop in the surface area and on the low water quality of the Seine estuary, the main river of the Eastern Channel.

A geographic Information System (GIS) was used to develop quantitative maps of sole nursery habitats in the Eastern Channel by using a habitat suitability model based on bathymetry and sediment structure. This approach indicated that juvenile densities are low in the Seine estuary with regards to other nursery sectors. Then, thanks to historical maps of the Seine estuary, habitat suitability maps were built for key dates in the modifications of this estuary since 1850 . This backward predictive approach suggests that habitat loss in the Seine estuary has led to a $42 \%$ decrease of its nursery capacity. As the density of juvenile sole in the Seine estuary is low in comparison to other sectors, this represents only a $3 \%$ loss at the sole population scale, in the Eastern Channel. However, when we assumed that prior to anthropogenic disturbance the juvenile density in the Seine estuary might have been equivalent to the current density of adjacent sectors with higher quality, the loss in abundance could be nearly $23 \%(8-36 \%)$. Results suggest that the loss in habitat surface combined with habitat degradation has led to an important loss in the contribution of the Seine estuary nursery to the whole sole population in the Eastern Channel.
\end{abstract}

Keywords: Solea solea; Nursery; Habitat Mapping; Anthropogenic Disturbance; Seine Estuary; Recruitment 


\section{INTRODUCTION}

Estuaries and coastal areas are essential fish habitat because they act as nursery grounds for various marine fish species (Miller et al., 1984; Beck et al., 2001; Able, 2005). Juvenile growth and survival are determined by both the capacity and quality of these nursery habitats (Rijnsdorp et al., 1992; Gibson, 1994; Iles and Beverton, 2000). The increase of human activities along rivers, estuaries and in coastal areas affects ecosystems, in particular by pollution and habitat destruction (Coleman et al., 2008; Diaz and Rosenberg, 2008; Halpern et al., 2008). Habitat degradation is one of the most serious threats for the recovery of fish stocks (Hall, 1998). Quantitative and qualitative factors related to anthropogenic disturbance (Meng et al., 2000; Phelan et al., 2000) influence the quality of coastal and estuarine nurseries and thus recruitment and renewal of populations (Burke et al., 1993; Johnson et al., 1998; Cowan et al., 2000; Peterson et al., 2000; Scharf, 2000; Ferber, 2001; Thrush et al., 2008).

The inshore waters of the Eastern Channel (ICES Division VIId; Fig. 1) support nursery areas for several commercially important species, especially the common sole (Solea solea, L.) (Riou et al., 2001). The Bay of Seine is the largest estuary in the Eastern Channel and is thereby a potentially important nursery ground. However, this sector is highly disturbed through channel dredging, constructions of dikes and harbour extensions, which have substantially reduced the estuary area and subsequently suitable juvenile fish habitats, such as shallow muddy areas ( $>75 \%$ decrease; (Lesueur, 1999)). In addition, concentrations of organic chemical contaminants are high in this estuary, it being among the most contaminated in Europe (Gilliers et al., 2006), with episodes of oxygen depletion (Billen and Poulin, 1999). Thus, human disturbances have affected, perhaps reduced the nursery function of this estuary (Le Pape et al., 2007): its contribution to the renewal of flatfish stocks in the Eastern Channel is currently low (Riou et al., 2001) and fish growth performance and population density are significantly lower than in other nursery areas (Gilliers et al., 2006).

The present study aims to quantify the effects of human disturbance on sole nursery grounds in the Seine estuary and establish their consequences on the sole population of the Eastern Channel. A habitat suitability model, constructed for the recent period, was used in combination with historical habitat maps to provide backward projections of the potential juvenile sole densities. A two step approach was used: 1) A quantitative map of sole nursery habitats in the Eastern Channel during recent times was first developed in a Geographic Information System (GIS). A database was built by collating trawl surveys undertaken throughout the coastal and estuarine parts of the Eastern Channel during the three last decades. A generalized linear model (GLM) was developed to identify key factors explaining variations of juvenile sole densities in various habitats, featured by different subregions, bathymetry and sediment structure. Using this GLM and a GIS, key sites for the early life-history stages of sole were identified. 2) Historical maps of the Seine estuary were used to construct habitat suitability maps for key dates in the modifications of this estuary since 1850 . Combining the historical suitability maps and the GLM model of sole densities, the historical productions of the Seine estuarine nursery were calculated and related to its contribution to the sole population. 


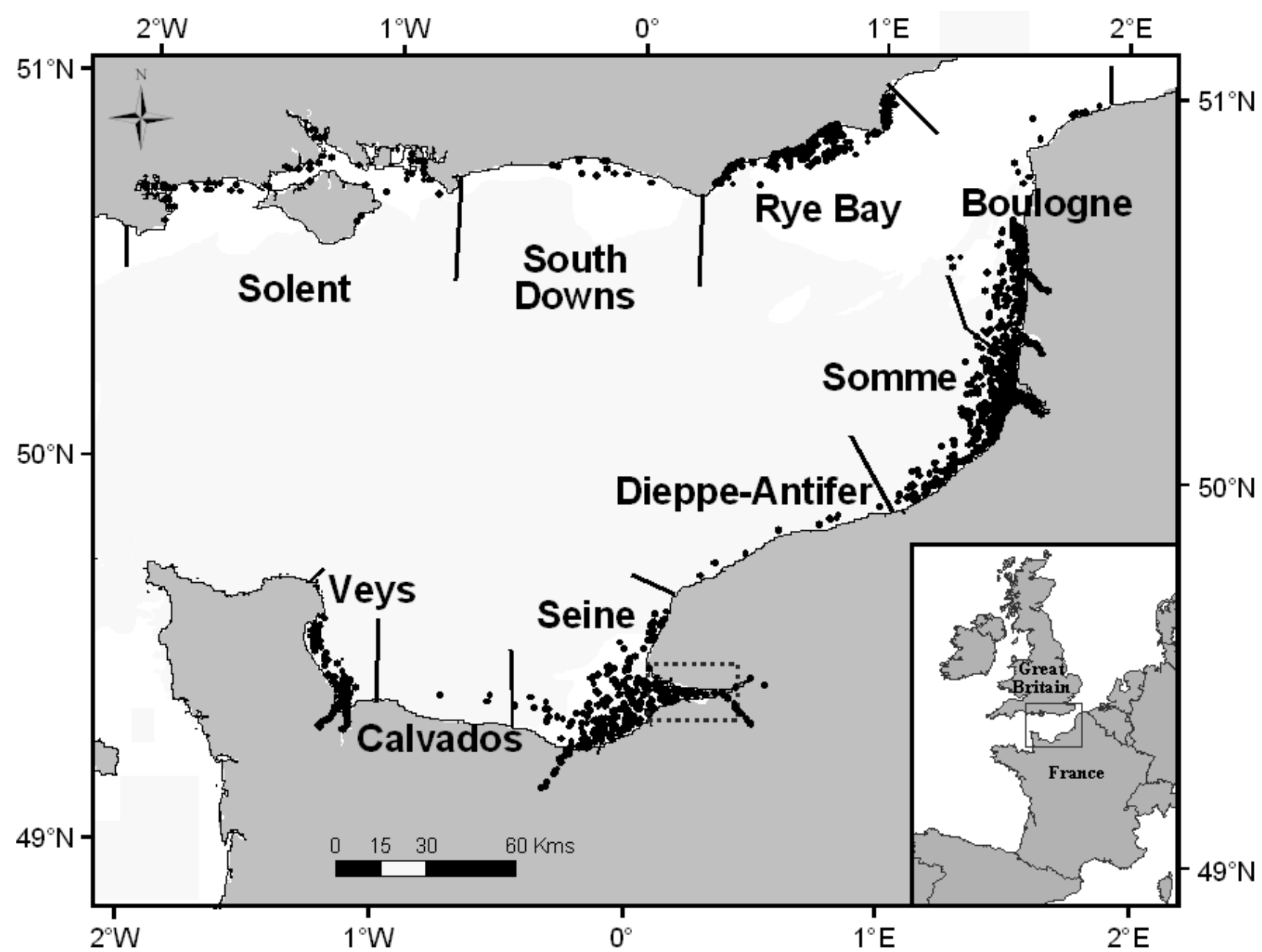

Fig. 1. Division of the Eastern Channel in 9 coastal and estuarine sectors. The dotted rectangle represents the internal Seine estuary. Points represent the position of the trawling stations, generally repeated annually during the survey periods (Table 1).

\section{Material AND MEthods}

\subsection{Survey data and numeric maps of physical habitat}

\subsubsection{Beam trawl survey data}

From 1974 to 2007, different beam trawl surveys focused on juvenile flatfish species have been undertaken throughout the Eastern Channel coastal zone (Fig.1, Table 1). Riou et al. (2001) collated these survey data until 1998. Data used in the present study were for a large part identical to this database, with an upgrade with the surveys undertaken between 1999 and 2007 (UK surveys on the English coast, French surveys in the downstream of the Seine estuary and in the Bay of Somme). In 2006, French estuaries and bays of the Eastern Channel (Bay of Veys, Orne, Seine, Somme, Canche and Authie) were investigated (Courrat et al., 2009) in the context of the European Water Framework Directive. These new surveys provided additional data in the inner part of these estuaries, until the upstream limit of freshwater.

To standardize our approach, we selected the surveys that were carried out between the end of August and the beginning of October. This period covers the time between the settlement of soles on nursery grounds and their autumnal migration (Dorel et al., 1991). Low mobility and relatively fixed distribution pattern of juvenile sole at this season (Dorel et al., 1991) allow us to consider the 
samples taken at this period as being representative of the distribution on nursery grounds. This season is also the most documented (90\% of the scientific trawl hauls). The resulting database includs about 5300 trawl hauls (Table 1), spread between French and English coasts (Fig. 1).

During the surveys, beam trawl hauls were performed only in daylight, at a towing speed ranging from 1.5 to 3 knots; 5 different gears were used (Table 1). For each beam trawl, soles were collected and measured in order to determine their age and age groups $(0,1$ or $2+)$ were validated from otolith reading. Densities of sole by age group were expressed as the number of fish caught per unit of trawled surface $\left(1000 \mathrm{~m}^{2}\right)$. Densities of the first cohort, young-of-the-year (YoY in the following), were selected for this study.

Table 1. Sampling protocol in the different nursery sectors

\begin{tabular}{lccc}
\hline Sector & Number of hauls & $\begin{array}{c}\text { Period of } \\
\text { investigation }\end{array}$ & $\begin{array}{c}\text { Gear } \\
(\text { BT }=\text { Beam Trawl })\end{array}$ \\
\hline Bay of Veys & 119 & $1977-1981$ & BT4 \\
& & & BT3 \\
Bay of Seine & 529 & $1977-1978 ; 1981$ & BT1 \\
& & $1995-2002$ & BT4 \\
& & & BT2a \\
Somme & 1383 & 2006 & BT3 \\
& & $1977-1983$ & BT1 \\
& & $1987-2006$ & BT4 \\
Boulogne & 315 & 2006 & BT2a \\
& & $1977-1983$ & BT3 \\
RyeBay & 1596 & $1987-2006$ & BT4 \\
South Downs & 268 & 2006 & BT3 \\
Solent & 1137 & $1974 ; 1981-2006$ & BT1 \\
& & $1974 ; 1981-1999$ & BT2b \\
& & & BT2b \\
\end{tabular}

\subsubsection{Physical descriptors of nursery habitat at the Eastern Channel scale}

Bathymetry and sediment structure are known to influence habitat suitability (Rijnsdorp et al., 1992). Thus, these physical factors have to be collected and linked to trawl data to estimate their influence on YoY habitat suitability and to develop habitat maps. Digital maps of factors were collected in this aim:

- A map indicating the coastline and the bathymetry (Loubrieu et al., 2008), available as continuous numerical values on a grid (resolution $=500 \mathrm{~m}$ ).

- A map for the sediment structure originally scanned from a paper map with a scale of $1 / 500000$, transformed to a grid with a resolution of 500m (Larsonneur et al., 1982). The sediment structure was simplified in three classes: mud (including mud and sandy mud), sand (including sand and muddy sand) and gravels (including all coarser sediments). Rocky sectors, not investigated with beam trawl surveys, were not taken into account. This description based on granulometry is parsimonious but complex enough to allow a good description of juvenile sole distribution (Riou et al., 2001). 
Other factors as hydrodynamism or coastal morphology influence larval supply and habitat suitability and thus the distribution of juvenile soles (Riou et al., 2001; Le Pape et al., 2003b). These factors were synthesized in a "sector" effect. The Eastern Channel was divided in 9 sectors (Fig. 1): Solent, the coast of South Downs, the Bay of Rye, the coast near Boulogne, the area off the Somme estuary, the coast between Dieppe and Antifer, the Seine estuary, the coast of Calvados and the Bay of Veys.

Two of these coastal sectors, Calvados and Dieppe-Antifer, were previously shown as covered with rocky sediments and thus not significantly used as nursery grounds (Riou et al., 2001). Hence, there were not taken into account.

\subsubsection{Historical evolution of the physical habitat in the Seine estuary}

One aim of the study was to map and evaluate the effects of habitat destruction. For that purpose, we focused on the Seine estuary, which suffered from a decline of its area related to anthropogenic modifications during the last two centuries. During this period, about a third of the historical internal estuarine area became terrestrial, which led to a loss of $75 \%$ of muddy sediment (Lesueur, 1999) and important modifications to the bathymetry. Quantified estimates of these evolutions were available through historical maps of sediment and bathymetry (Avoine, 1981; Garnaud, 2001); SHOM (Service Hydrographique et Océanographique de la Marine, Brest, France); Port of Rouen, France). We chose to work with maps representing key periods in changes of the internal estuary: 1850, 1910, 1980 and present (Fig 2). For the survey period, between 1980 and present, maps of bathymetry and sediment structure were available more frequently (one map for each decade).
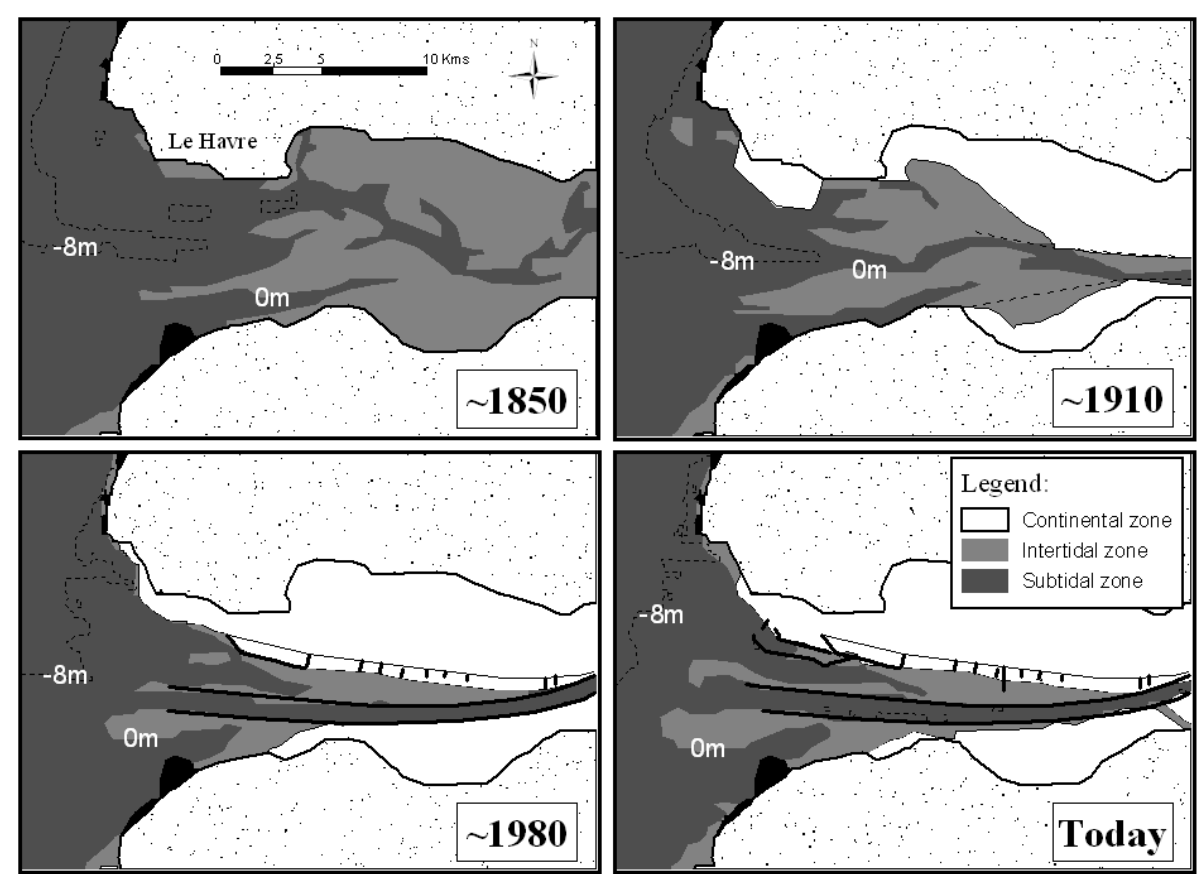

Fig. 2. Historical morphologic changes in the internal Seine estuary. (From Delsinne, 2005) 


\subsection{Coupling trawl data survey to habitat descriptors}

\subsubsection{Allocation of physical descriptors to survey data}

Physical descriptors (bathymetry and sediment structure) and coastal sectors were included in a GIS, which allowed different layers of data to be intersected and stratified on the basis of these three parameters.

The Seine estuary received a particular attention. Because the morphology of this estuary has been strongly modified during the sampling period, the available decadal maps have been used to identify physical descriptors in this area. For the other sectors, we assumed modifications during the sampling period to be insignificant and thus, the spatial repartition of physical factors over the three decades to be constant.

Information on physical and geographical factors was combined with survey data. The latter, identified from the mean position of the trawl haul were included in the GIS in order to associate bathymetry, sediment structure and geographic sector to each trawl.

\subsubsection{Limit to the upstream extension of sole nursery grounds in estuaries}

Maps of bathymetry and sediments were limited to the downstream part of the estuaries, where juvenile soles may live. We assumed oligohaline waters, i.e. lower than 5 PSS (Anon., 1959), to be exempt of juvenile soles since the entry of juvenile soles into estuaries is controlled by salinity (Gibson, 1994). Fonds (1975) showed that the survival range of salinity for young soles was between 6 and 60 PSS. Moreover, in our database, no juvenile soles were hauled for salinities under 8 PSS. The mean limit of 5 PSS was identified on maps, for the main estuaries of the Eastern Channel, thanks to Avoine (1981), Avoine et al. (1996) and salinities measured during surveys and completed with expert knowledge (S. Duhamel (CSLHN), pers. comm.). Because of tidal movements and changes in rivers discharge, the limit of 5 PSS in estuaries does not correspond to a fixed line. However, compared to the Eastern Channel scale, the potential error due to the movement of this salinity limit appeared negligible.

\subsubsection{Intercalibration of beam trawl data}

The trawl dataset was compiled from surveys using five types of beam trawl (BT) (Table 2). The abundance indices data were standardized to correct for the gear effects, accounting for the presence of tickler chain, the mesh size and the width of the trawl (Riou et al., 2001), three factors, which are known to influence the gear efficiency and selectivity. Thus, for each trawl raw data, the standardization of caught densities $\left(\boldsymbol{Y o} \boldsymbol{Y}_{\text {caught }}\right)$ was corrected as follows:

$$
\text { YoY } Y_{\text {corrected }}=F_{\text {Tickler chain }} \times F_{\text {Mesh size }} \times F_{\text {width }} \times Y_{\text {Oo }} Y_{\text {caught }}
$$

The correction for the presence of tickler chain was calculated from field intercalibration depending on age groups and sediment structure (Riou et al., 2001). Its effect was not significant on muddy sediments, thus the correction was applied for chainless trawls used on sandy sediments and on gravels only, by using $F_{\text {no chain, sand }}=4.85$ (Riou et al., 2001). 
Table 2. Features of the beam trawls. See text for the method used to compute the standardization factor accounting for the mesh size $\left(\mathrm{F}_{\mathrm{M}}\right)$.

\begin{tabular}{lccc}
\hline Gear & Width $(\mathrm{m})$ & Mesh $(\mathrm{mm})$ & $\mathrm{F}_{\mathrm{M}}$ \\
\hline BT1 & 1.6 & 15 & 0.88 \\
BT2a & 2 & 20 & 1 \\
BT2b & 2 & 6 & 0.84 \\
BT3 & 2.9 & 20 & 1 \\
BT4 & 4.4 & 25 & 1.19 \\
\hline
\end{tabular}

The effect of the mesh size ( $\boldsymbol{F}_{\text {Mesh size, }}$ noted $\left.\boldsymbol{F}_{M}\right)$ depends on the length distribution of fish. Thus, to intercalibrate catches, we calculated a correcting factor for each gear, depending on its mesh $(\boldsymbol{M})$ $\left(\boldsymbol{F}_{\boldsymbol{M}}\right)$. The length-frequency distribution of YoY was available for about only $13 \%$ of hauls of the database, representing about 1600 fish lengths $(\boldsymbol{L})$, equally distributed between surveys (if all the fish were measured during the surveys, for a large part of the hauls, data were archived in age structure after allocation from length distribution and otolith validation). However, the fish length data were not available for each different mesh size $(\boldsymbol{M})$. Thus, a two-step approach was used to calculate each correcting factor $\left(\boldsymbol{F}_{M}\right) .1$ ) The theoretical length-frequency distribution of the original population $\left(N_{o}(L)\right)$ was reconstructed on the basis of catches. 2) The proportion of the theoretic population caught by each mesh size was calculated.

The first step of the approach was based on Eq. (2). A preliminary evaluation showed that spatial and annual variations of the mean length were low and had an influence lower than 5\% on the estimates of correcting factors $\left(\boldsymbol{F}_{\boldsymbol{M}}\right)$. Hence, a unique population has been reconstructed, of which the size structure was based on the largest available amount of measured YoY (1600) caught with different mesh sizes:

$$
N_{o}(L)=\sum_{M} \frac{N_{\operatorname{caught}(M)}(L)}{S_{M}(L)}
$$

where $N_{o}(L)$ is the recalculated amount of juveniles at length $L, N_{\text {caught }(M)}(\boldsymbol{L})$ is the amount of catches for the mesh size $\boldsymbol{M}$ at length $\boldsymbol{L}$ and $\boldsymbol{S}_{M}(\boldsymbol{L})$ is the theoretic proportion of fish of length $(\boldsymbol{L})$ caught by a trawl with a mesh size $(\boldsymbol{M})$. The calculation of $\boldsymbol{S}_{M}(\boldsymbol{L})$ is detailed in Table 3. 
Table 3. Calculation of the mesh-depending selectivity coefficients $\left(\boldsymbol{S}_{M}(\boldsymbol{L})\right)$ for each $1 \mathrm{~cm}$ body length class (L) from Dardignac and de Verdelhan. (1978).

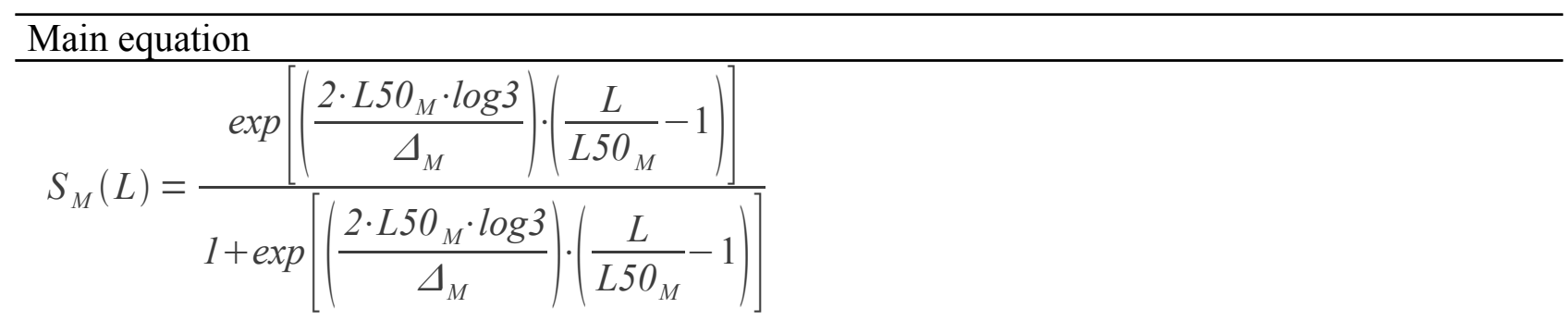

\begin{tabular}{|c|c|}
\hline Parameters & \\
\hline$L 50_{M}=\alpha \cdot M$ & $\begin{array}{l}\text { The } 50 \% \text { retention length depending on the species and the mesh size in } \mathrm{cm} \text {. } \\
(\alpha=3.3 \text { for the common sole; Anon, } 1978 ; 1998)\end{array}$ \\
\hline$\Delta_{M}=\beta . L 50_{M}$ & $\begin{array}{l}\text { The selectivity range representing the difference between } \boldsymbol{L} \mathbf{7 5}_{M} \text { and } \boldsymbol{L} \mathbf{2 5} \mathbf{5}_{M} \text {, } \\
\text { respectively the } 75 \% \text { and the } 25 \% \text { retention lengths and considered } \\
\text { common to every species }(\beta=0.385 ; \text { Anon., } 1978 ; 1998)\end{array}$ \\
\hline
\end{tabular}

Then, the total proportion of the theoretic population caught by each gear $\left(\boldsymbol{P}_{\boldsymbol{M}}\right)$, depending on the mesh size, was calculated (Eq. 3):

$$
P_{M}=\frac{\sum_{L} N_{o}(L) \cdot S_{M}(L)}{\sum_{L} N_{o}(L)}
$$

where $N_{o}(L)$ is the amount of fish of length $\boldsymbol{L}$ of the previously reconstructed population.

This calculation allowed to estimate an intercalibration factor for each gear with mesh size $\boldsymbol{M}$ $\left(\boldsymbol{F}_{\boldsymbol{M}}\right)$ according to the mesh size used (Eq. 4), as if every hauls had been sampled with the same reference gear using a $20 \mathrm{~mm}$ mesh size $\left(\boldsymbol{F}_{\boldsymbol{M}=2 \boldsymbol{0}}=1\right)$ :

$$
F_{M}=\frac{P_{M=20}}{P_{M}}
$$

The resulting multiplying factors $\left(\boldsymbol{F}_{\boldsymbol{M}}\right)$ are reported in Table 2.

The influence of the width of the trawl was not taken into account, as its effect was not significant. This effect depends on the ability of fish to escape laterally, hence depends on the length of juveniles. Kuipers (1975) showed a difference in catchability of plaice between beam trawl of $2 \mathrm{~m}$ and $4 \mathrm{~m}$. We used these results to conduct a preliminary sensitivity analysis on our dataset. This showed that our method was robust to the effect of trawl width, especially because both the difference between the width of BT1, BT2 and BT3, and the representation of BT4 (6\%) in the data set were low. This conclusion was reinforced by examination of the influence of trawl width between BT2 (width $=2 \mathrm{~m}$ ) and BT3 (width $=2.9 \mathrm{~m}$ ) in the intercalibration data set of Riou et al. (2001). This examination showed no influence of the width of the trawl while comparing densities and length distribution profiles of juvenile catches between BT2 and BT3 having the same mesh size. The difference in trawl width between these two trawls is likely to be too small to detect any effect of lateral escape. 


\subsubsection{The bathymetry, from a continuous descriptor to a class factor}

Shallow waters are identified to be habitat for juvenile soles (Koutsikopoulos et al., 1989; Le Pape et al., 2003b). Thus, predictions were limited to waters down to $20 \mathrm{~m}$. Note that in the database, no juvenile soles were caught in stations deeper than $21 \mathrm{~m}$.

Furthermore, although it was available as a continuous variable, bathymetry was split in classes. This approach was justified by two arguments: 1) Hauls could only be associated to a range of bathymetry instead of a precise one. Indeed, the precision of the map used to attribute bathymetry (Loubrieu et al., 2008) was smaller than the length of trawl hauls. Actually, the resolution of the map was 500m, whereas hauls were ranged between $500 \mathrm{~m}$ and $2000 \mathrm{~m}$ long; 2) Integrating bathymetry as a continuous variable would have been complicated as its effect on the distribution of juveniles was non-linear. In order to choose the range of classes, generalized additive models (GAM) were used to explore the relation between YoY densities and continuous bathymetry. Classes of bathymetry were identified from changes in slopes for densities of juveniles against bathymetry.

Bathymetry was split into 7 classes (Fig. 3) : [-8;-3[, [-3;0[, [0;3[, [3;5[, [5;8[, [8;13[ and [13;20] meters. This partition was consistent with the shape of evolution of the probability of presence (Fig. 3a) and positive densities (Fig. 3b) with bathymetry. Moreover, it provided a way to distribute the data in the classes as equitably as possible (Fig. 3c).
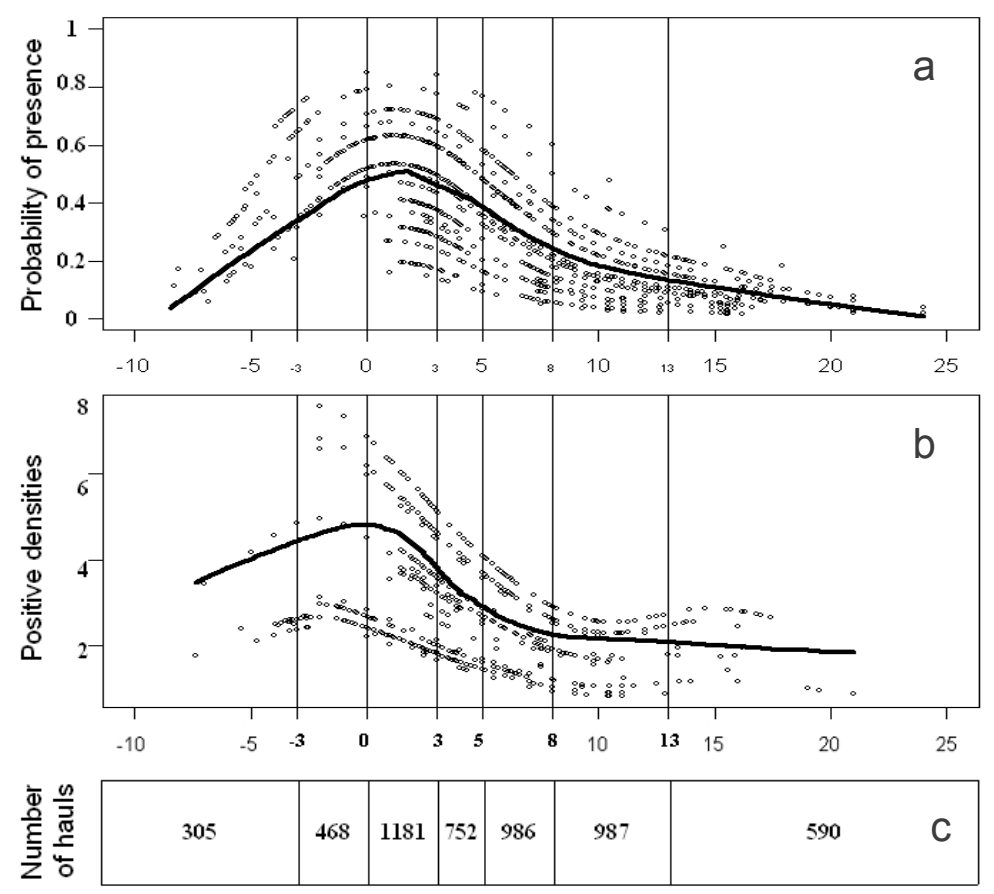

Fig. 3. GAMs prediction of the distribution of YoY survey data with regard to bathymetry (line is the smoothed prediction): (a) probability of presence of YoY (b) positive densities of YoY. Vertical lines represents the chosen limits of classes. (c) Numbers of trawl hauls in each class of bathymetry. 


\subsection{Habitat suitability model}

Habitat suitability for YoY soles was defined using a GLM that included "Sector", "Bathymetric class" and "Sediment structure" as descriptive factors; Riou et al. (2001) previously showed the relevance of using this combination of physical and geographic factors to describe juvenile soles spatial distribution in this Eastern Channel. Abundance indices data are typical zeroinflated data, characterized by an important proportion of zero values $(67 \%$ of zero values in the present trawl survey dataset for YoY densities). This non-Gaussian data distribution prohibited the use of a classical statistical approach and a Delta model was used (Stefanson, 1996; Le Pape et al., 2003b; Martin et al., 2005). The Delta model is a conditional approach coupling two sub-models: 1) A first model testing for the presence of YoY; 2) A second model explaining the variation of the densities in habitats where presence was recorded. Three steps are needed to build this model:

a. In the first sub-model, the binary presence/absence of juvenile soles is used as a response variable. The model is built from a GLM based on a binomial distribution with a probability of presence $\left(\mathbf{p}_{\mathbf{0} / 1}\right)$ that linearly depends upon factors through a logit link function:

$$
\text { Logit }\left(p_{0 / 1}\right)=\text { Constant }+ \text { Sector }+ \text { Bathymetry }+ \text { Sediment }
$$

b. The second sub-model uses a Gaussian linear model on log-transformed positive densities to normalize the skewed distribution of the data. Preliminary analyses showed that a Gaussian distribution on log-transformed data was the best option to describe positive values (Le Pape et al., 2003):

$$
\begin{aligned}
& \log (\mathrm{YoY}+) \sim \text { Constant + Sector + Bathymetry + Sediment + } \varepsilon \\
& \text { with } \varepsilon \sim N\left(0, \sigma_{r e s}{ }^{2}\right)
\end{aligned}
$$

c. Finally, for each site $\boldsymbol{i}$, the predictions of these two sub-models are combined to obtain the habitat suitability indices for each combination of factors. This combination has to account for the correction of Laurent (1963) to obtain an unbiased point estimate from a linear model based on log-transformation for each habitat $\boldsymbol{i}$ :

$$
H S I_{(i)}=\hat{p}_{0 / 1(i)} \cdot \exp (\hat{\log }(Y o Y+(i))) \cdot \exp \left(1 / 2 \cdot \hat{\sigma}_{r e s}^{2}\right)
$$

It is worth noting that the effect of interannual variability was not taken into account for two reasons. First, the aim of the study was not to assess the interannual variations of the density but to build a mean habitat suitability model standing for the recent period, then to provide backward projections of the mean potential densities based on historical habitat maps. Second, the sampling plan was non-regular (Table 1). Several sectors were not sampled all the years. So, accounting for a "year" effect in the model would have lead to confusion between "year" and "sector" effects that would have been difficult to hand with. In this analysis, all variations in YoY relative densities were attributed to habitat features. 


\subsection{Coupling model and GIS}

\subsubsection{Mapping the present Eastern Channel nursery grounds}

Results of the habitat suitability model were included in a GIS to calculate an index of juvenile abundance based on estimated densities on each cell of the grid map and on surface of the respective habitats.

Maps of physical and geographic descriptors used to project the results were rasters based on a regular grid. At each point of the grid, a bathymetric class, a class of sediment and a sector were attributed, which gave the possibility to predict indices from the estimates of the habitat suitability model. Then, the combination of the raster grid (surface) with the habitat suitability model (density) allowed to calculate a juvenile abundance index for each sector (number of fish $=$ surface $\times$ density). It was then possible to estimate the potential contribution of the different nursery sectors to the total population in the Eastern Channel as a percentage of this abundance in the overall area (Riou et al., 2001; Le Pape et al., 2003b).

\subsubsection{Mapping historical Seine estuarine nursery}

The model has been applied to estimate previous juvenile abundances in the Seine estuary according to historical habitat maps for the last two centuries. However, a thorny problem remained with how to deal with the "sector" effect in the past centuries. Indeed, the potential of the Seine estuary as nursery ground with relation to water quality has certainly changed during the two last centuries but remained unknown.

The following approach was used to circumvent this problem. In a first analysis, we directly applied the results of the habitat suitability model on historical maps and calculated abundance for each map, considering that only the variations in the habitat surface and structure (bathymetry, sediment type) impacted the density. In this configuration, the "sector" effects in both the presence/absence and the model for positive densities were considered constant between the current situation and the historical time. The Seine "sector" effect can be considered as the "average YoY sole density" in the Seine estuary, around which the estimate density vary with different bathymetry and sediment types. In this analysis, the "average density" was considered constant over time.

In a second analysis, we assumed that two centuries ago, the quality of the Seine estuary and the related densities of juvenile sole were higher (Gilliers et al., 2006). To play this scenario, the mean densities in the Seine estuary in the 1850 s were modified through a variation of the Seine "sector" effect in the model. Considering the increase of anthropogenic pressure along the Seine River during the last two centuries, the contamination level of its estuary in the 1850s cannot have been worse than nowadays. Indeed, at present, the mean level of pollution in the Seine estuary for the last 20 years is the highest of French estuaries. By contrast, the Bay of Veys is one of the least polluted estuarine systems (Courrat et al., 2009). However, other factors as hydrodynamism, and their influence on larval supply, can have an effect on local densities of YoY (Pihl and van der Veer, 1992). Thus, the historical situation in the Seine estuary can not be assessed with certainty. Therefore, we assessed the sensitivity of historical YoY abundances to different values of the Seine sector effect. To achieve this goal, nursery grounds were mapped on the basis of the numerical maps in the 1850s, but the ultimate number of YoY hosted in the Seine estuary were estimated with the "sector" effect successively set equal to gradually increasing "sector" effects within the range of 
values obtained for all the other sectors (min sector effect $=\mathrm{S}$. Downs; max sector effect $=$ RyeBay). In this sensitivity analysis, the mean sector effect of the Bay of Veys was considered as the "reference" level for potential historical situation in the Seine estuary. Indeed, these two sectors are close each other (Fig. 1) and depend on the same spawning ground for their larval supply (Lee and Ramster, 1979). It is therefore consistent to consider that the huge difference between the "sector effects" of the Seine and the Bay of Veys is related to habitat and water quality, and especially to levels of contamination which are much higher in the Seine estuary.

Results were first used to estimate the consequences of habitat degradation on the nursery capacity in the internal Seine estuary (Fig. 2). Then, the consequences at the scale of the Eastern Channel (Fig. 1) were estimated. In this way, habitat suitability maps were used to calculate an index of the amount of YoY hosted in each nursery sector and the same index was calculated in the Seine sector for the historical periods. This allowed the consequences of habitat loss on the YoY abundance in the Seine estuary and on the total amount of YoY in the Eastern Channel (population scale, (Riou et al., 2001)) to be estimated.

\section{Results}

\subsection{Distribution of YoY in the Eastern Channel at the present time}

All factors except the "sediment" had a significant effect in the two sub-models (Table 4). The "Sediment" effect was not significant $(\mathrm{p}=0.4)$ in the sub-model for positive densities (Table 4). This factor was then excluded from this sub-model.

Table 4. Analysis of deviance for the two parts of the delta log-normal GLM

\begin{tabular}{|c|c|c|c|c|c|c|}
\hline \multirow[t]{2}{*}{ Added variables } & \multicolumn{3}{|c|}{ Binomial model $\left(\operatorname{logit}\left(\mathrm{p}_{0 / 1}\right)\right)$} & \multicolumn{3}{|c|}{ Positive value model (YoY + ) } \\
\hline & $\begin{array}{l}\text { Residual } \\
\text { degrees } \\
\text { of } \\
\text { freedom }\end{array}$ & $\begin{array}{c}\text { Explained } \\
\text { deviance } \\
(\%)\end{array}$ & Significance & $\begin{array}{l}\text { Residual } \\
\text { degree of } \\
\text { freedom }\end{array}$ & $\begin{array}{c}\text { Explained } \\
\text { deviance } \\
(\%)\end{array}$ & Significance \\
\hline Null & 5262 & & & 1677 & & \\
\hline \multicolumn{7}{|c|}{ YoY $\sim$ Sector + Bathymetry + Sediment $(E q .5$ and 6$)$} \\
\hline Sector & 5256 & 3.9 & $\mathrm{p}<10^{-61}$ & 1671 & 6.1 & $\mathrm{p}<10^{-19}$ \\
\hline Bathymetry & 5250 & 10.0 & $\mathrm{p}<10^{-125}$ & 1665 & 5.2 & $\mathrm{p}<10^{-23}$ \\
\hline Sediment & 5248 & 0.9 & $\mathrm{p}<10^{-11}$ & \multicolumn{3}{|c|}{ Non significant } \\
\hline
\end{tabular}

When considering the effect of the different factors obtained from the delta model (Fig. 4), differences between sectors are markedly pronounced (Fig. 4a): on average, the highest YoY densities (RyeBay) reached 5.2 times the smallest ones (South Downs). The differences are also important when considering bathymetry (Fig. 4b): on average, densities are 8.9 times higher in the second class $([-3 ; 0[)$ compared to the last one $([13 ; 25])$. An optimum in the distribution of 0 -group soles appears for low bathymetry $([-3 ; 0[)$. Results indicate a significant preference for finer sediments (mud), but the differences between "sediment" effects are rather weak (Fig. 4c): on average, "Mud" effect is almost 1.8 times the "Gravels" effect. 

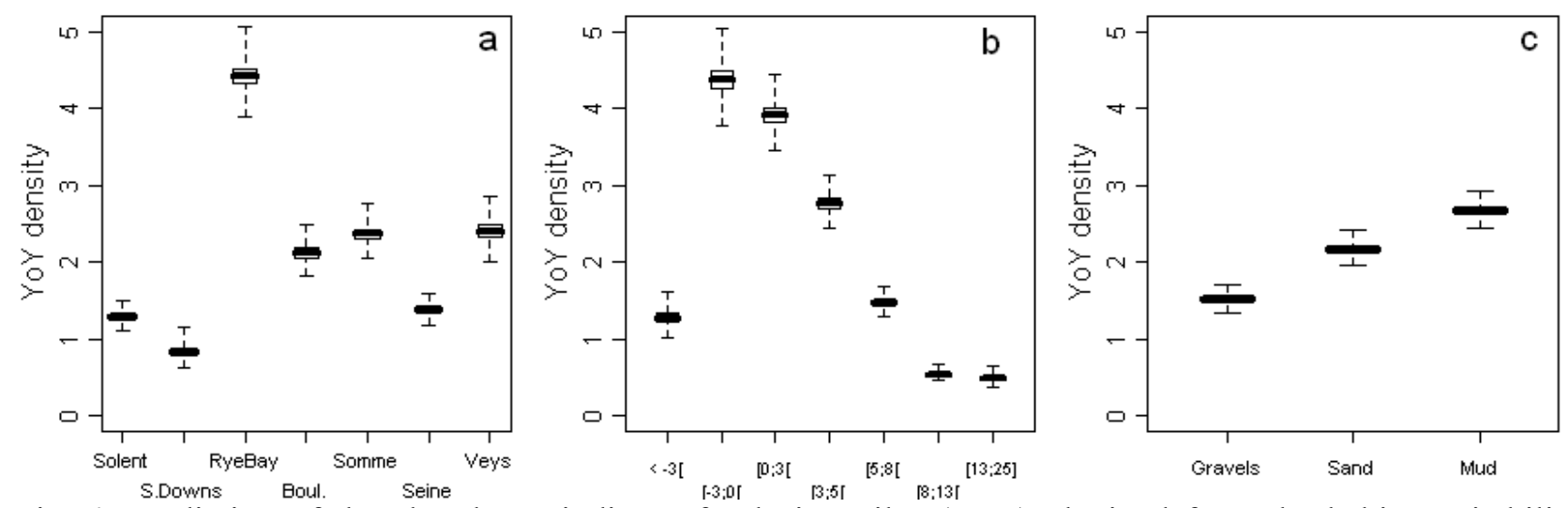

Fig. 4. Prediction of the abundance indices of sole juveniles (YoY) obtained from the habitat suitability delta-GLM model: (a) average sector effect, (b) average effect of Bathymetry and (c) average effect of sediment. Average effects were obtained from the predictions of the delta-GLM (Eq. 7). For instance, the average Seine sector effect (panel (a)) was obtained from the following method: for each combination of the other factors bathymetry and sediment, a prediction of the abundance indices was obtained from Eq. (7). The predictions for each combination of factor were then averaged to get the mean Seine effect. Uncertainty was estimated by Monte Carlo sampling (5000 trials) in the estimation distribution of each parameters needed to compute the prediction in Eq. (7).

The combination between the delta model and the GIS (Fig. 5a) revealed that juveniles are concentrated in limited coastal sectors close to the shore. Differences between YoY densities in the different nursery sectors are also well marked, particularly while considering rich (Rye Bay, Bay of Veys) and poor (South Downs, Seine) neighbor areas.

The contribution of the different sectors to the total amount of YoY at the population scale appears much contrasted (Fig. 5b), with relation to the combined effect of both the surface of each sector and the "sector" effect. If we focus on the Seine sector, results highlight that, although the Seine is the single large river reaching the Eastern Channel, its estuary still represents only 17\% of the nursery surface, less than the Somme, and contributes only $14 \%$ to the amount of YoY for the population. 


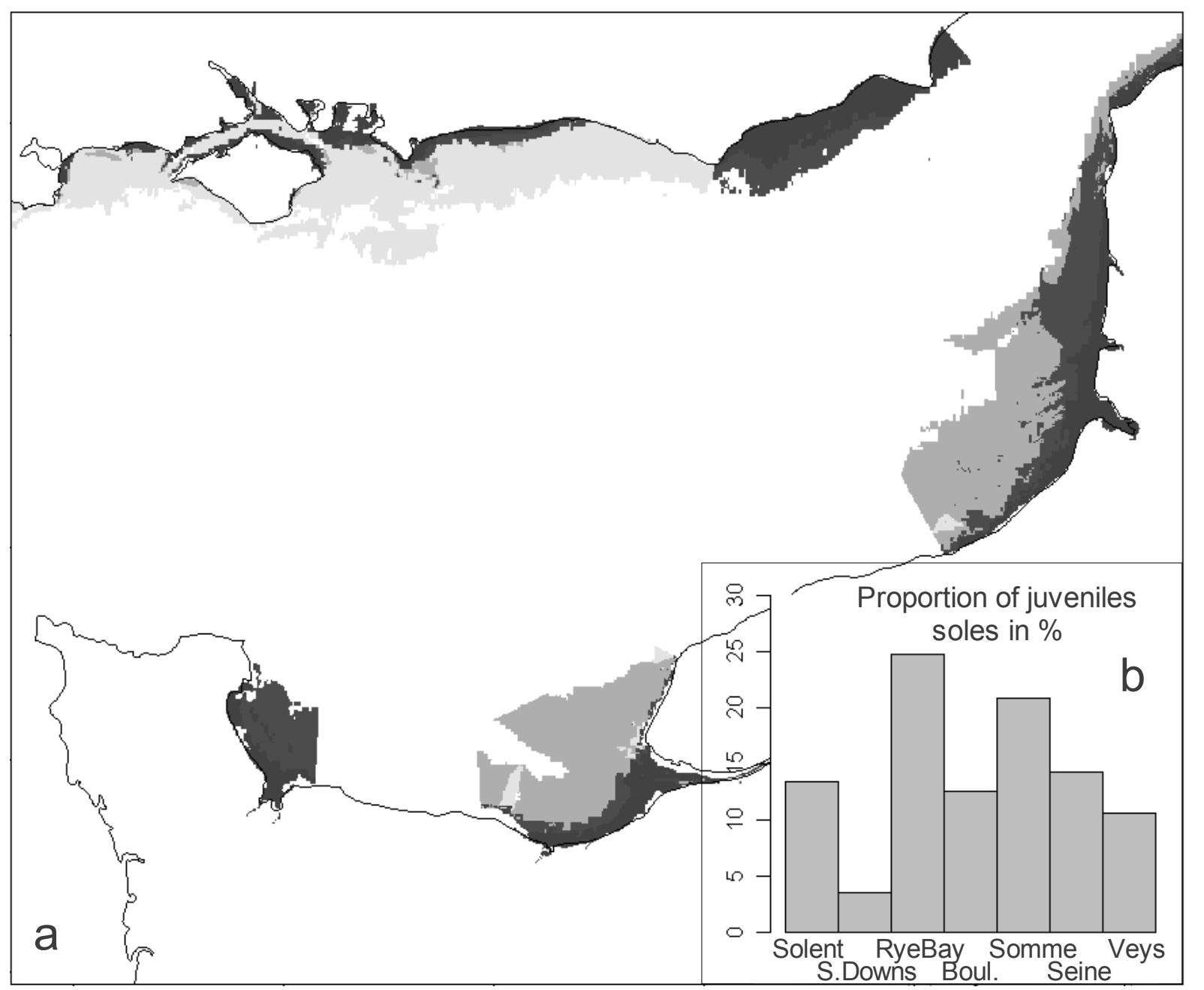

Fig. 5. (a) Distribution of YoY soles abundance indices in the Eastern Channel based on predictions of the delta model for each cell of the grid map (\$2.4.1). The grey scale represents densities from low to high. (b) Contribution of each nursery sector to the population (proportion in \%).

\subsection{Effect of two centuries of transformation in the Seine estuary}

\subsubsection{Loss in YoY production due to reduced nursery surface}

Fig. 6a highlights the drop of the nursery surface in the internal Seine estuary due to successive steps in the construction of dikes and harbour's enlargement (Fig. 2), and the subsequent changes in juveniles' distribution. Modifications of the internal part of the Seine estuary transformed 33\% of its surface of potential nursery ground to terrestrial area. This led to a $42 \%$ loss of juvenile production (Fig. 6b) because of surface loss and changes in bathymetry and sediment structure.

Considering that there were no historical changes in YoY densities, these modifications of the Seine estuary led to a $4 \%$ loss of the total number of juveniles at the population scale since 1850 (Fig. 7a). 

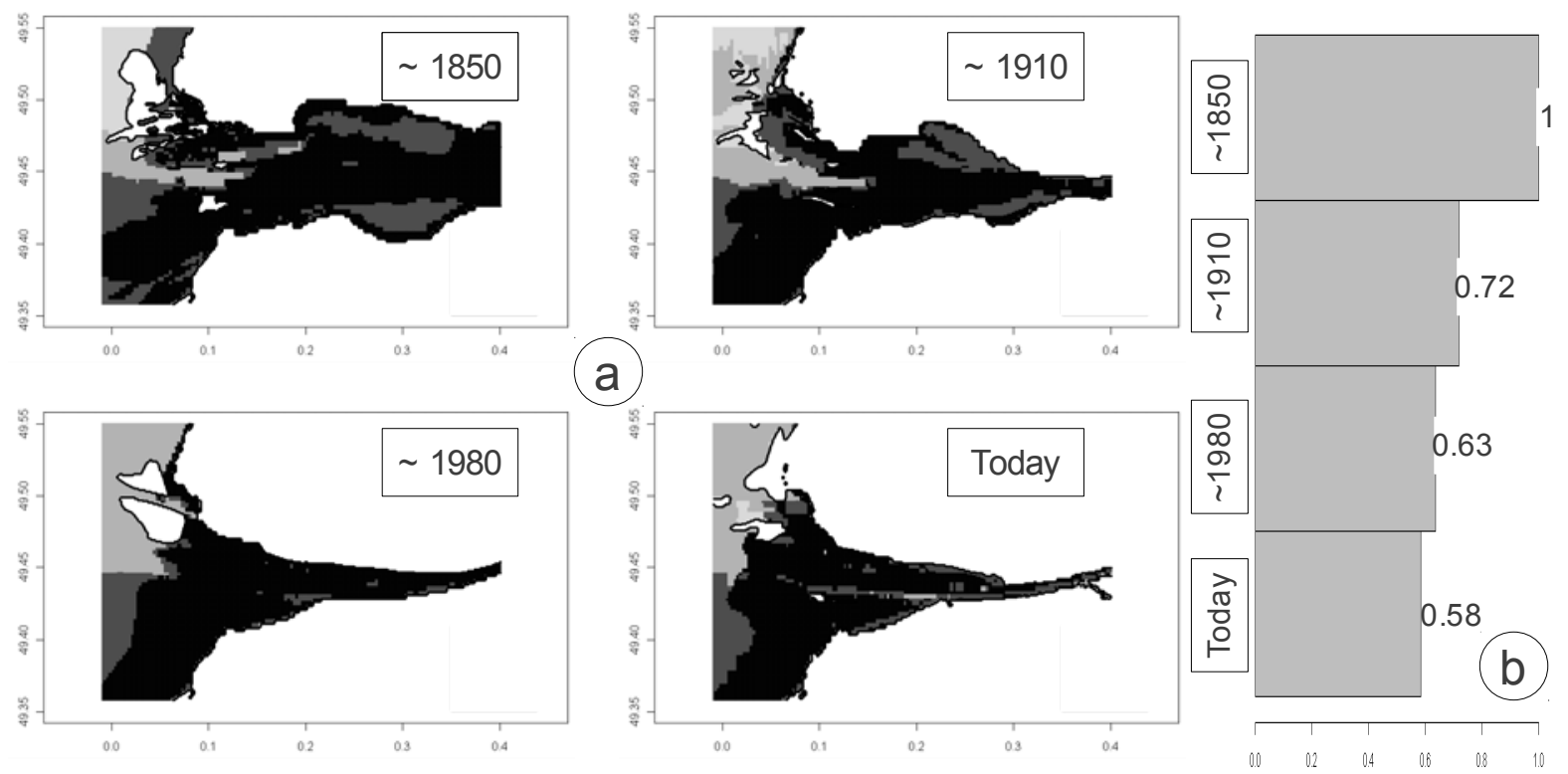

Fig. 6. (a) Maps of projected abundance indices at different dates of historical changes in the internal Seine estuary. The darker is the grey, the more YoY abundance indices is high. (b) Relative amount of YoY in the internal Seine estuary by reference with 1850 .

\subsubsection{Loss in YoY production due to reduced nursery surface and habitat quality degradation}

The analysis of the consequences of historical changes in YoY densities in the Seine estuary considered the "sector" effects represented on fig. 4a. First, the adjacent Bay of Veys "sector" effect was considered as a supposed realistic situation of the average YoY density in the Seine estuary before massive disturbance of water quality. This was quite equivalent to double $(\times 1.7)$ the current Seine "sector" effect (Fig. 4a). When the increase in the estuarine surface and this simulated increase of the habitat quality were combined in the backward projections of YoY densities in the Seine estuary, the contribution of the Seine sector raised $28.5 \%$ of the amount of YoY in the Eastern Channel in the 1850s compared to 14\% nowadays. Consequently, the estimated impact of the habitat degradation in the Seine estuary consisted in a loss reaching $17 \%$ of the total YoY production (Fig. 7b). This is a largely higher loss rate than the $4 \%$ calculated when considering the impact of reduction of the habitat surface only.

These simulations were completed in a sensitivity analysis by setting successively the historical Seine "sector" effect at the level of the Somme and the Rye Bay (Fig. 4a). This consisted in multiplying by 1.7 and 3.2 the current Seine "sector" effect. When considering these values, the contribution of the Seine sector was between $16 \%$ and $41 \%$ of the production of the Eastern Channel in the 1850s and the impact of the habitat degradation in the Seine estuary led to a loss of $15 \%$ to $32 \%$ of the total YoY production. 

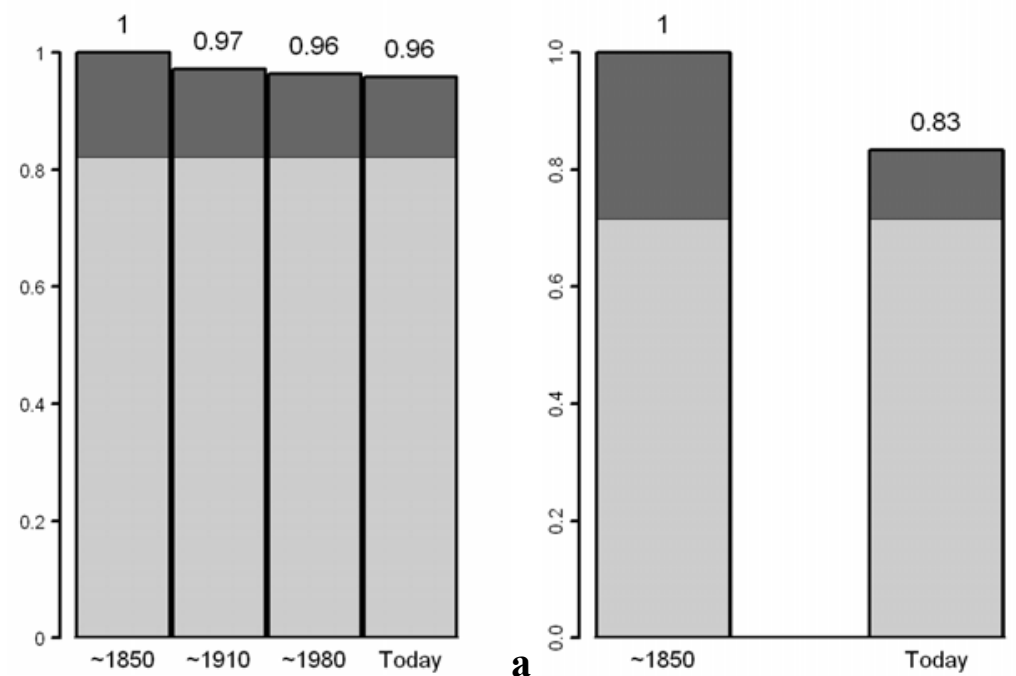

b

Fig. 7. Trends in relative abundance of YoY sole in the Eastern Channel since 1850 assuming (a) only a loss in habitat surface in the Seine estuary, the quality in each sector remaining constant along time, (b) a loss in habitat surface in the Seine estuary combined with a drop in water quality. The quality of the estuary in 1850 is assumed equivalent to the one of the Bay of Veys in the 2000s'. In dark grey, the contribution of the Seine estuary. In light grey, sum of other sectors' contributions.

\section{Discussion}

\subsection{An approach based on several hypotheses: overview of possible bias}

To model the effect of habitat degradation in the Seine estuary, a habitat suitability model based on scientific surveys undertaken during the past 30 years was coupled with a GIS that incorporated actual and historical maps. Several methodological points could be discussed and improved in future research.

\subsubsection{Habitat suitability models, bias and source of non explained variability}

Our approach was based on robust parsimonious models for habitat modelling and historical projections. Although historical approaches can provide notable results, they may also face large uncertainty because these habitat suitability models are based on few descriptive factors, and explained only a low part of the variability in YoY densities.

The meso-scale physical descriptors combined with trawl survey data did not account for smallscale variability that occurs in juvenile flatfish distribution (Rogers, 1992; Allen and Baltz, 1997; Nicolas et al., 2007; Stoner et al., 2007; Vinagre et al., 2009). Other descriptors could surely significantly increase the part of the variability explained by nursery habitat models. However, descriptors cannot be used for mapping if they are not themselves available as maps (Le Pape et al., 2003b). For instance, accounting for benthic macrofauna would certainly improve the description of sole nursery habitat (Vinagre et al., 2006; Nicolas et al., 2007) but the lack of maps of benthic invertebrates at the Eastern Channel scale prevented to use this factor for nursery mapping. This conclusion is reinforced for such historical approach, as historical maps are very scarce and only available for few physical descriptors when considering the two last centuries.

Interannual variability of YoY densities was not included in the models. The habitat model was averaged over the last three decades in order to estimate the effect of mesoscale habitat variables 
and to use these effects for historical backward estimations. In fact, considering a "year" effect in the model would not have been possible as the sampling plan was not regular over sectors and years. However, averaging over several years is consistent with the concept of effective habitats (Dahlgren et al., 2006). This approach also fits with the use of historical maps of sediment and bathymetry that represent the situation over an extended period of time, rather than a precise year. Moreover, there were no historical surveys to tune a "year" effect for the last two centuries.

Hence, the lack of survey data and the limited availability of descriptors for the past periods mean that the historical approach faces important uncertainties. Nevertheless, the approach provides a way to quantify the historical consequences of anthropogenic disturbances.

\subsubsection{Are changes in the Seine estuary the single ones in the Eastern Channel?}

We considered the variations of the YoY production due to modifications in the Seine estuarine nursery only, without taking into account possible habitat modifications in other coastal and estuarine nursery grounds.

Clearly, habitat degradations occurred in other nursery sectors since the $1850 \mathrm{~s}$. The Eastern channel is characterised by substantial urban and industrial development, resulting in heavy inputs of chemical contaminants, as well as significant loss or alteration of marine habitat in some locations (Amara et al., 2007). Several important harbours are located along this coastline and other sectors of the Eastern Channel have also faced, to a lesser extent, harbours extension, piers and dikes building and channel dredging. Moreover, no significant restoration-monitoring program has been led in this area, except for recent limited experiments in the Seine estuary.

However, although no precise quantitative estimations of changes in other sectors exist, some expertise allows considering that modifications have not been as important as in the Seine estuary. Thus, our analysis enables to capture an important part of the production loss due to the habitat reduction and degradation at the scale of the Eastern Channel. Because habitat loss and degradation also occurred elsewhere, the present results provide a lower bound for the consequences of anthropogenic disturbance at the scale of the Eastern Channel.

\subsection{The negative effect of habitat degradation on estuarine capacity}

The contribution of each nursery sector to the Eastern Channel population depends on its geographical situation and its capacity to offer an adequate environment (Gibson, 1994). Both habitat size and quality influence juvenile production in nursery grounds, and thus recruitment strength (Gibson, 1997). The combined influences of the loss in habitat surface and quality of the Seine estuary were considered in this analysis.

\subsubsection{Consequences of loss in surface of estuarine habitat}

Quantitative mapping provides useful tool to determine the area of juvenile habitats from a Geographic Information System (GIS), and their respective contribution to the total production (GIS area $\times$ density derived from the model; (Riou et al., 2001; Le Pape et al., 2003b). As historical maps of the descriptors were available, this tool allowed an assessment of the consequences of habitat loss.

With such an approach, we observed the impact of habitat loss in the Seine estuary on the YoY sole production. The loss in surface of nursery habitat explained a $42 \%$ drop of the nursery capacity 
in the internal part of the Seine estuary, with regards to pre-industrial period. This reduction of the nursery capacity alone led to a loss of $4 \%$ of the total juvenile production in the Eastern Channel.

However, the current configuration of the Seine estuary suggests that the river flow is now stronger than in the past. This channelled estuary probably prevents a large number of juveniles to go up to the inner estuary, on highly productive grounds. Hence, this probable effect, which cannot be calculated because of a lack of maps and field data, is likely to be low compared to the important loss of habitat in the Seine estuary and insignificant at the scale of the Eastern Channel.

\subsubsection{Combination of loss in habitat surface and quality}

Given its bio-geographical features, the potential nursery function of the Seine estuary should have been greater in the past, before anthropogenic disturbance (Riou et al., 2001; Gilliers et al., 2006; Le Pape et al., 2007). The Seine is the single large river in the Eastern Channel and the potential nursery function of its estuary should have been higher than exposed coasts (Le Pape et al., 2003b, 2003), at least in the same range as other estuaries of the Eastern Channel. As the present results confirmed that YoY densities are especially low in the Seine estuary, the effect of the habitat surface loss combined with hypothesis on habitat degradation were assessed in a second part of the historical approach. In this scenario, the average densities of the other sectors of the Eastern Channel were considered as indices for the average past densities in the Seine estuary. The density of sole in pristine conditions is unknown, but this sensitivity analysis gave a likely range of the possible level of the historical Seine production. This hypothesis led to increase YoY densities in the Seine estuary from 1.7 to 3.2 times the current one. This led to an estimated loss ranging between $15 \%$ and $32 \%$ of the total Eastern Channel production between the 1850 s and nowadays.

The current level of YoY densities in the Bay of Veys is considered to represent the best approximation of the historical production of the Seine estuary. Indeed, the density of juvenile in the coastal zone results from 2 controlling factors (Le Pape et al., 2003b): (1) Larval supply: all coastal sectors do not receive the same number of sole larvae. (2) Habitat quality and suitability. The Bay of Veys is an adjacent nursery of the Bay of Seine. The geographical position of the spawning area (Lee and Ramster, 1979) and the relative protection of both these sectors from the high currents existing in the Eastern Channel (Hoch and Garreau, 1998) suggest that they are supplied with a comparable level of larvae. On the contrary, the other sectors, chosen as references for the sensitivity analysis, are located at the eastern part of the Eastern Channel. They may have a higher larval supply as 1-day eggs densities are 5 times higher in this area compared to the common spawning area for Bay of Veys - Seine (Anon., 1986). Estimating the potential past densities of YoY in the Seine estuary by considering the Bay of Veys as a reference for the past average densities enabled to approximate the effect of habitat degradation to a loss of $23 \%$ of the Eastern Channel population.

The Bay of Veys is one of the less polluted sector in the Eastern Channel (Courrat et al., 2009), in contrast to the Seine estuary which is the most polluted one. The difference in average densities between these two sectors does not seem to be related to larval supply, but is likely to be due to the lower habitat quality in the Seine estuary caused by intense anthropogenic pressure. In fact, the Seine estuary is known to be highly contaminated and habitat degradation is known to have a strong negative impact. Several human related factors like eutrophication (Eby et al., 2005; Shimps et al., 2005; Diaz and Rosenberg, 2008), chemical contamination (Johnson et al., 1998; Peterson et al., 
2003) lead to a disturbed nursery function (Able et al., 1999; Coasta and Cabral, 1999; Jones et al., 2002; Whitfield and Elliot, 2002; Coates et al., 2007). Gilliers et al. (2006) and Amara et al. (2007) focused on these negative consequences of low water quality on residual sole nursery habitats: in the Seine estuary, juvenile sole are in lower density, grow slower and are in a lesser condition than in preserved nursery sectors. Thus, low ecological performance of the Seine estuary as sole nursery ground was probably due to its low quality, and especially oxygen depletion (Billen and Poulin, 1999) and chemical contamination (Gilliers et al., 2006; Amara et al., 2007; Courrat et al., 2009).

\subsection{The effect of human disturbance on estuarine systems for marine resources}

As described in the concentration hypothesis (Iles and Beverton, 2000), nursery dependent species possess a high degree of compensation caused by damping density-dependent effects (DingSor et al., 2007) related to nursery habitat capacity. This is especially verified for flatfish (van der Veer et al., 2000) and specifically for the common sole (Le Pape et al., 2003a). The population renewal is therefore directly limited by the capacity (size and quality) of available nursery areas (Rooper et al., 2004).

As illustrated in the present study consequences of habitat loss on nursery capacity combined with decrease of water quality appear of general concern on coastal and estuarine essential fish habitats worldwide. First, estuarine and coastal transformations have dramatically accelerated worldwide over the past 150 to 300 years (Lotze et al., 2006) and this trend is not slowing down (Coleman et al., 2008). Such habitat losses affect nursery size and, as demonstrated in the present study, recruitment of marine population. This conclusion about muddy areas on estuaries can be generalized as degradation of coastal and estuarine fish habitats is verified on estuarine systems (van Dyke and Wasson, 2005) but also on seagrass (Pihl et al., 2006), mangroves (Faunce and Serafy, 2006; Kavanagh, 2007) and coral reefs (Hoegh-Guldberg, 2006; Mumby et al., 2007). Second, impact of habitat degradation and lower quality of nursery also affect marine fish recruitment. Sole and other species that use estuaries and coastal waters as nurseries are of particular concern. Densities and species richness of marine juvenile fishes using estuarine and coastal nursery grounds appeared to be strongly and negatively correlated to habitat quality (Courrat et al., 2009). Thus, human disturbances, and the related degradation of the quality of residual habitats, impact the nursery function of estuaries.

The present study hence provides insights for the assessment of the consequences of anthropogenic disturbance on estuarine dependent marine fish species (Miller et al., 1984; Lenanton and Potter, 1987; Gibson, 1994; Elliott and Dewailly, 1995; Elliott et al., 2007; Franco et al., 2008). Estuarine habitat degradation may drastically impact the sustainability of marine resources. Important related fisheries (Peterson, 2003; Fodrie and Mendoza, 2006) are affected. Hence, it is essential to maintain habitat size and quality of estuarine nursery habitats to preserve sustainable resources and fisheries.

\section{AcKnowledgements}

This project was supported by the French National Research Agency (ANR, Project SoleBeMol-Pop, ANR Vulnérabilité, Milieux et climat). Special thanks to Franck Coppin (Ifremer, Boulogne sur Mer, France) and Marie Laure Cochard (Ifremer, Port en Bessin, France) for their 
help on collection of trawl survey data, Mario Lepage and his colleagues (Cemagref, Bordeaux, France) for their help in gathering trawl data of the Water Framework Directive, Michel Bellouis and Benoit Loubrieu (Ifremer, Plouzané, France), Sandrine Vaz (Ifremer, Boulogne Sur Mer, France), Sylvain Duhamel (Cellule de Suivi du Littoral Haut Normand, Le Havre, France), for their assistance to collect numeric maps of the Eastern Channel and Nicolas Bacq (Seine Aval, Rouen, France) for providing historical maps of the Seine estuary.

The authors also want to thank the reviewers for their fruitful comments.

\section{REFERENCES}

Able, K.W. 2005. A re-examination of fish estuarine dependence : Evidence for connectivity between estuarine and ocean habitats. Estuarine,coastal and shelf science 64:5-18.

Able, K.W., Manderson, J.P. \& Studholme, A.L. 1999. Habitat quality for shallow water fishes in an urban estuary: the effects of man-made structures on growth. Mar. Ecol. Prog. Ser. 187:227-235.

Allen, R.L. \& Baltz, D.M. 1997. Distribution and microhabitat use by flatfishes in a Louisiana estuary. Environmental Biology of Fishes 50:85-103.

Amara, R., Meziane, T.G.C., Hermel, G. \& Laffargue, P. 2007. Growth and condition indices in juvenile sole Solea solea measured to assess the quality of essential fish habitat.

Anon. 1959. The final resolution of the symposium on the classification of brackish waters. Venice 8-14th April 1958. Archivio di Oceanografia e Limnologia 11, 243-248, .

Anon. 1986. Report of the ad hoc working group on the 1984 and 1985 sole (Solea solea L.) egg surveys.

Avoine, J. 1981. L'estuaire de la Seine: sédiments et dynamiques sédimentaire. PhD thesis, Univ. Caen.

Avoine, J., Lesueur, P. \& Rouault, T. 1996. Evolution morphologique et couverture sédimentaire de l'estuaire de la Seine: actualisation et fluctuations. Pages 2-20.

Beck, M.W., Heck, K.L., Able, K.W., Childers, D.L., Eggleston, D.B., Gillanders, B.M., Halpern, B., Hays, C.G., Hostino, K., Minello, T.J., Orth, R.J., Sheridan, P. \& Weinstein, M.P. 2001. The role of nearshore ecosystems as fish and shellfish nurseries. bioscience 51:633-641.

Billen, G. \& Poulin, M. 1999. L'oxygčne. Un témoin du fonctionnement microbiologique. Programme Scientifique Seine-Aval, Fascicule 5:30pp.

Burke, J., Peters, D. \& Hanson, P. 1993. Morphological indices and otolith microstructure of Atlantic croaker, Micropogonias undalatus, as indicators of habitat quality along an estuarine pollution gradient. Environmental Biology of fishes 36:25-33.

Coasta, M.J. \& Cabral, H.N. 1999. Changes in the Tagus nursery function for commercial fish species: some perspectives for management. Aquatic Ecology 33:287-292.

Coates, S., Waugh, A., Anwar, A. \& Robson, M. 2007. Efficacy of a multi-metric fish index as an analysis tool for the transitional fish component of the Water Framework Directive.

Coleman, J.M., Huh, O.K. \& DeWitt B. 2008. Wetland loss in world deltas.

Courrat, A., Lobry, J., Nicolas, D., Laffargue, P., Amara, R., Lepage, M., Girardin, M. \& Le Pape, O. 2009. Anthropogenic disturbance on nursery function of estuarine areas for marine species. Estuarine, Coastal and Shelf Science 81:179-190. 
Cowan, J.H., Rose, K.A. \& de Vries, D.R. 2000. Is density dependent growth in young of the year fishes a question of critical weight? Rev. Fish Biol. and Fish. 10:61-89.

Dahlgren, C.P., Kellison, G.T., Adams, A.J., Gillanders, B.M., Kendall, M.S., Layman, C.A., Ley, J.A., Nagelkerken, I. \& Serafy, J.E. 2006. Marine nurseries and effective juvenile habitats: concepts and applications. Marine Ecology-Progress Series. 312:291-295.

Diaz, R.J. \& Rosenberg, R. 2008. Spreading deadzones and the consequences for marine ecosystems.

DingSor, G.E., Cianelli, L., Chan, K.S., Ottersen, G. \& Stenset, N.C. 2007. Density dependence and density independence during the early life stages of four marine fish stocks.

Dorel, D., Koutsikopoulos, C., Desaunay, Y. \& Marchand, J. 1991. Seasonal distribution of young sole (Solea solea (L.)) in the nursery ground of the Bay of Vilaine (Northern Bay of Biscay). Netherlands Journal of Sea Research 27:297-306.

van Dyke, E. \& Wasson, K. 2005. Historical ecology of a central california estuary: 150 years of habitat change. Estuaries 28:173-189.

Eby, L.A., Crowder, L.B., McClellan, C.M., Peterson, C.H. \& Powers, M. 2005. Habitat degradation from intermittent hypoxia: impacts on demersal fishes. MEPS 291:249-262.

Elliott, M. \& Dewailly, F. 1995. The structure and components of european estuarine fish assemblages. Netherlands Journal of Aquatic Ecology 29:397-417.

Elliott, M., Burdon, D., Hemingway, K.L. \& Apitz, S.E. 2007. Estuarine, coastal and marine ecosystem restoration: Confusing management and science: A revision of concept.

Faunce, C.H. \& Serafy, J.E. 2006. Mangroves as fish habitat: 50 years of field studies. Marine Ecology-Progress Series 318:1-18.

Ferber, D. 2001. Keeping the stygian waters at Bay. Science 291:968-973.

Fodrie, F.J. \& Mendoza, G. 2006. Availability, usage and expected contribution of potential nursery habitats for the Clifornia halibut. Estu. Coast Shelf Sci. 68:149-164.

Fonds, M. 1975. The influence of temperature and salinity on growth of young sole Solea solea L. 10th European Symposium on Marine Biology, Ostend, Belgium, Sept. 17-23 1:109-125.

Franco, A., Elliott, M., Franzoi, P. \& Torricelli, P. 2008. Life strategies of fishes in European estuaries: the functional guild approach.

Garnaud, S. 2001. La sédimentation fine sur une plate-forme interne actuelle macrotidale: la baie de Seine sud-orientale (France). $\mathrm{PhD}$ thesis, Univ. Caen.

Gibson, R.N. 1994. Impact of habitat quality and quantity on the recruitment of juvenile flatfishes. Netherlands Journal of Sea Research 32:191-206.

Gibson, R.N. 1997. Behaviour and the distribution of flatfishes. Journal of Sea Reseach 37:241-256.

Gilliers, C., Le Pape, O., Desaunay, Y., Morin, J., Guerault, D. \& Amara, R. 2006. Are growth and density quantitative indicators of essential fish habitat quality ? An application to the common sole Solea solea nursery grounds. Estuarine, Coastal and Shelf Science 69:96-106.

Hall, S.J. 1998. The effects of fishing on marine ecosystems and community. Blackwell Science, Oxford.

Halpern, B.S., Walbridge, S., Selkoe, K.A., Kappel, C.V., Micheli, F., D'Agrosa, C., Bruno, J.F., Casey, K.S., Ebert, C., Fox, H.E., Fujita, R., Heinemann, D., Lenihan, H.S., Madin, E.M.P., Perry, M.T., Selig, E.R., Spalding, M., Steneck, R. \& Watson, R. 2008. A global map of human impact on marine ecosystems. 
Hoch, T. \& Garreau, P. 1998. Phytoplankton dynamics in the English Channel : a simplified three dimensional approach. J Mar Sys 16.

Hoegh-Guldberg, O. 2006. Complexities of coral reef recovery. Science 311:42-43.

Iles, T.C. \& Beverton, J.H. 2000. The concentration hypothesis: the statistical evidence. ICES Journal of Marine Science 57:216-227.

Johnson, L.L., Landahl, J.T., Kubin, L.A., Horness, B.H., Myers, M.S., Collier, T.K. \& Stein, J.E. 1998. Assessing the effects of anthropogenic stressors on Puget Sound flatfish populations. Journal of Sea Research 39:125-137.

Jones, R.F., Baltz, D.M. \& Allen, R.L. 2002. Patterns of resource use by fishes and macroinvertebrates in Barataria Bay, Louisiana. Marine ecology progress series 237:271289.

Kavanagh, E. 2007. A world without mangroves?

Koutsikopoulos, C., Desaunay, Y., Dorel, D. \& Marchand, J. 1989. The role of coastal areas in the life history of sole (Solea solea L.) in the Bay of Biscay. Scientia marina 53:567-575.

Kuipers, B.R. 1975. On the efficiency of a two meter beam trawl for juvenile plaice (Pleuronectes platessa) in the Wadden sea. 9:69-85.

Larsonneur, C., Bouysse, P. \& Auffret, J. 1982. The superficial sediments of the English Channel and its western approaches. Sedimentology 29.

Laurent, A.G. 1963. The log-normal distribution and the translation method: description and estimation problems. Journal of American Statistical association 58:231-235.

Lee, A. \& Ramster, J. 1979. Atlas of the seas around the British Isles, 20 edition.

Lenanton, R.C. \& Potter, I.C. 1987. Contribution of estuaries to commercial fisheries in temperate Western Australia and the concept of estuarine dependence. Estuar. 10:28-35.

Le Pape, O., Baulier, L., Cloarec, A., Martin, J., Le Loc'h, F. \& Desaunay, Y. 2007. Habitat suitability for juvenile common sole (Solea solea, L.) in the Bay of Biscay (France): A quantitative description using indicators based on epibenthic fauna. Journal of Sea Research 57:126-136.

Le Pape, O., Chauvet, F., Desaunay, Y. \& Guerault, D. 2003a. Relationship between interannual variations of the river plume and the extent of nursery grounds for the common sole (Solea solea, L.) in Vilaine Bay. Effects on recruitment variability. Journal of Sea Research 50:177185.

Le Pape, O., Chauvet, F., Mahevas, S., Lazure, P., Guerault, D. \& Desaunay, Y. 2003 b. Quantitative description of habitat suitability for the juvenile common sole (Solea solea, L.) in the Bay of Biscay (France) and the contribution of different habitats to the adult population. Journal of Sea Research 50:139-149.

Le Pape, O., Gilliers, C., Riou, P., Morin, J., Amara, R. \& Desaunay, Y. 2007. Convergent signs of degradation in both the capacity and the quality of an essential fish habitat: state of the Seine estuary (France) flatfish nurseries. Hydrobiologia 588:225-229.

Le Pape, O., Holley, J., Guerault, D. \& Desaunay, Y. 2003. Quality of coastal and estuarine fish habitats: estimations based on the size of juvenile common sole (Solea solea L.). Estuarine, Coastal and Shelf Science 58:793-803.

Lesueur, P. 1999. Sables chenaux et vasičres, Dynamique des sédiments et évolution morphologique. 3:38. 
Lotze, H.K., Lenihan, H.S., Bourque, B.J., Bradbury, R.H., Cooke, R.G., Kay, M.C., Kidwell, S.M., Kirby, M.X., Peterson, C.H. \& Jackson, J.B.C. 2006. Depletion, Degradation, and Recovery Potential of Estuaries and Coastal Seas. Science 312:1806-1809.

Loubrieu, B., Bourillet, J. \& Moussat, E. 2008. Bathy-morphologie régionale du Golfe de Gascogne et de la Manche, Modèle numérique 2008.

Martin, T.G., Wintle, B.A., Rhodes, J.R., Kuhnert, P.M., Field, S.A., Low-Choy, S.J., Tyre, A.J. \& Possingham, H.P. 2005. Zero tolerance ecology: improving ecological inference by modelling the source of zero observations. Ecology Letters 8:1235-1246.

Meng, L., Gray, C., Talpin, B. \& Kupcha, E. 2000. Using winter flounder growth rates to assess habitat quality in Rhode Islands coastal lagoons. Mar. Ecol. Prog. Ser. 201:287-299.

Miller, J.M., Reed, J.P. \& Pietrafesa, L.J. 1984. Patterns, mechanisms and approaches to the study of migrations of estuarine dependent fish larvae and juveniles. J.D. McCleave, G.P. Arnold, J.J. Dodson, W.H. Neill (eds), Mechanisms of migration in fishes Plenum Press, New York:209-225.

Mumby, P.J., Hastings, A.H. \& Edwards, J.E. 2007. Thresholds and the resilience of Caribbean coral reefs.

Nicolas, D., Le Loc'h, F., Desaunay, Y., Hamon, D., Blanchet, A. \& Le Pape, O. 2007. Relationship between benthic macrofauna and habitat suitability for juvenile common sole (Solea solea, L.) in the Vilaine estuary (Bay of Biscay, France) nursery ground. Estuarine coastal ans shelf science 73:639-650.

Peterson, C., Grabowski, J. \& Powers, S. 2003. Estimated enhancement of fish production resulting from restoring oyster reef habitat: quantitative valuation. Marine Ecology Progress Series 264:249-264.

Peterson, C.H., Summerson, H.C., Thomson, E., Lenihan, H.S., Grabowski, J., Manning, L., Micheli, F. \& Johnson, G. 2000. Synthesis of linkages between benthic and fish communities as key to protecting essential fish habitat. Bulletin of Marine Science 66:759774.

Peterson, M. 2003. A conceptual view of environment-habitat-production linkages in tidal river estuaries. Reviews in Fisheries science 11:291-313.

Phelan, B.A., Goldberg, R., Bejda, A.J., Pereira, J., Hagan, S., Clark, P., A.L., S., Calabrese, A. \& Able, K.W. 2000. estuarine and habitat related differences in growth rates of young of the year winter flounder (Pseudopleuronectes americanus) and tautog (Tautoga onitis) in three northeastern US estuaries. J. Exp. Mar. Biol. and Ecol. 247:1-28.

Pihl, L., Baden, S., Kautsky, N., Ronnback, P., Soderqvist, T., Troell, M. \& Wennhage, H. 2006. Shift in assemblage structure due to loss of seagrass Zostera marina habitat sin Sweden. Estuarine, Coastal and Shelf Science 67:123-132.

Pihl, L. \& van der Veer, H. 1992. Importance of exposure and habitat structure for the population density of 0-group plaice, Pleuronectes platessa L., in coastal nursery areas. Netherlands Journal of Sea Research 29:145-152.

Rijnsdorp, A.D., van Beek, F.A., Flatman, S., Millner, R.M., Riley, J.D., Giret, M. \& De Clerck, R. 1992. Recruitment of sole stocks, Solea solea (L.), in the northeast Atlantic. Netherlands Journal of Sea Research 29:173-192. 
Riou, P., Le Pape, O. \& Rogers, S. 2001. Relative contributions of different sole and plaice nurseries to the adult population in the Eastern Channel: application of a combined method using generalized linear models and a geographic information system. Aquatic Living Resources 14:125-135.

Rogers, S.I. 1992. Environmental factors affecting the distribution of sole (Solea solea(L.)) within a nursery area. Netherlands Journal of Sea Research 29:153-161.

Rooper, C., Gunderson, D. \& Armstrong, D. 2004. Application of the concentration hypothesis to English sole in nursery estuaries and potential contribution to coastal fisheries. Estuaries 27:102-111.

Scharf, F. 2000. Patterns in abundance, Growth, and Mortality of Juvenile red drum across estuaries on the Texas coast with Implications for recruitment and stock enhancement. Transactions of the American Fisheries society 129:1207-1222.

Shimps, E.L., Rice, J.A. \& Osborne, J.A. 2005. Hypoxia tolerance in two juvenile estuarydependent fishes. Journal of Experimental Marine Biology and Ecology 325:146-162.

Stefanson, G. 1996. Analysis of groundfish survey abundance data: combining the GLM and delta approaches. ICES Journal of Marine science 53:577-588.

Stoner, A.W., Spencer, M.L. \& Ryer, C.H. 2007. Flatfish-habitat associations in Alaska nursery grounds: Use of continous video records for multi-scale spatial analysis. Journal of Sea Research 57:137-150.

Thrush, S.F., Halliday, J., Hewitt, J.E. \& Lohrer, A.M. 2008. The effects of habitat loss, fragmentation, and community homogenization on resilience in estuaries.

van der Veer, H., Bergham, R., Miller, J. \& Rijnsdorp, A. 2000. Recruitment in flatfish, with special emphasis on North atlantic species: Progress made by the Flatfish Symposia. Ices Journal of Marine Science 57:202-215.

Vinagre, C., Fonseca, V., Cabral, H. \& Costa, M. 2006. Habitat suitability index models for juvenile soles, Solea solea \& S. senegalensis, in the Tagus estuary: defining variables for species management. Fisheries research 82:140-149.

Vinagre, C., Maia, A., Reis-Santos, P., Costa, M.J. \& Cabral, H.N. 2009. Small-scale distribution of Solea solea and Solea senegalensis juveniles in the Tagus estuary (Portugal). Estuarine, Coastal and Shelf Science 81:296-300.

Whitfield, A.K. \& Elliot, M. 2002. Fishes as indicators of environmentaland ecological changes within estuaries: a review of progress and some suggestions for the future. Journal of fish biology 61:229-250. 